\title{
Linguistic Adaptation to Speech Function
}

WILLIAM J. SAMARIN

It is because we look mostly at certain languages or because we are primarily interested in certain aspects of language that we still have an imperfect understanding of all the means and the motives of man's use of language. Despite the accessibility of virtually every language on the face of the earth and the ease with which we can observe, collect, and analyze la langue pratiquée - language in action - we continue to preoccupy ourselves with standard language, explicit texts, elicited data, and with problems made more amenable by the available stock of observations. We do not yet clearly understand, or have not described with compelling rigor and explicitness, the functions that language and speech have for man. And if we are in agreement at least about the irreducible inventory of functions, we have not gone far in describing the consequences of these functions for language structure and language use.

This paper deals with one of these functions, the expressive function. It demonstrates that expressiveness or affect is not merely a function of individual psychology and behavior in unconscious (unattended to, unmannered) and manipulated or edited speech. Expressiveness is not merely manifested in pragmatics - in the manner in which speech is constructed - but also in its structure. Moreover, languages differ significantly in the way they realize this universal function.

\section{LANGUAGE FUNCTIONS}

There has been no doubt about the authenticity of the expressive function I am indebted to Paul Kay for a sympathetic and critical reading of this paper and for the lively correspondence we have had over the question of the "autonomy" of African ideophones. 
of language. The main problem has been to find patterns, or structure, in its manifestation. For linguistics this meant discovering a direct link between function and form. Evidence for such a relationship has been scanty indeed.

Affect, as the common view would have it, is not the function of form but of use. "Every language is itself a collective art of expression," said Sapir (1921: 240), for example. Language merely provided resources at its different levels of structure. There is no necessary link between these resources and their use. It is simply that by convention a given community of speakers has been socialized to use such and such elements for a given purpose. It is an accident of history that "It was reported by the press" and "I read in the newspaper" suggest different feelings about the press as a source of information, about the topic being discussed, about the setting, etc. It is likewise an accident of history that "apartment" and "pad" refer to the same physical object but suggest different attitudes. This is the stuff of which style is made.

Some speech substances, according to the common view, nonetheless seem to have a closer relationship to function than syntax and lexicon. Even though volume, intensity, speed of utterance, etc. are inevitable components of the dynamics of speech, they are also more amenable to expressive manipulation. Their meaning is directly, if not intuitively, understood. They can be adjusted for subtle shades of meaning. But these phenomena have not been incorporated into the core of linguistic structure. A theory of language, according to the common view, does not have to explain their co-occurrence with nonprosodic elements.

Of even greater marginality is sound symbolism and onomatopoeia, although both phenomena are incontestably the means for the expression of affect. People do have a different feeling about words like squish and squash whatever may be the history of their emergence in the English language. Such oppositions are even recognized as being productive, and people create new contrasts (that is, apply the pattern to different sets of words) for immediate needs. Sound symbolism and onomatopoeia are combined, once again, productively, in sets like bink, bunk, bonk. For example, a cartoon in the New Yorker (1 July 1967, p. 27) depicts a knight in full armor lying prostrate at the bottom of a stairway. The history of his fall is recorded in this "sentence:" clink, clink, clink, clink [on level ground], clunk, clunk, clunk [down the stairs, then], bink, blong, splank, crash (volume of sound is indicated by increasing size of print).

Onomatopoeia by definition is evidence of linguistic license. (The term by common consent refers both to sound mimetic elements as well as those that evoke other concepts, for example, helter-skelter. A related term is 
introduced below.) Anyone can create a form, as I once did when I said, "The wind catches them [slips of paper], and they go ššsfff, like butterflies." This vocalization is not part of English or any language I know, and, if I had not recorded this event, I probably would not have been able to give a meaning for the neologism at a later date. It is not surprising that people use such words. What is remarkable, we have been told (Bühler 1969: 126), is how few of them there are in languages, even "primitive" ones. (However, because there are still a few people who believe that primitive languages exist, there are still people who believe that they have a more developed onomatopoeia, see for example, Slama-Cazacu [1961: 135].)

In summary, then, linguistic consensus appears to maintain that affect Is negligibly channeled through codified elements of linguistic structure. Expression is subservient to reference. This is true for all languages, for codified representation (arbitrariness) is what makes language. People who speak different languages are not more, or less, expressive; they are expressive in different ways. Likewise, some languages are not inherently more, or less, expressive; they simply provide different kinds of resources. The speaker of English, in this view, is not handicapped by comparison with the Russian or Italian (or is it just the Sienese?) who can mark the diminutive, for example, with great freedom.

Contemporary dogma, if it is not simplistic, is the result of premature generalization. There is abundant evidence that languages differ substantively - therefore significantly - in their response to expressive function. This is what I claim for African languages with a highly developed ideophony. (The term is explained below.) This is not to say, however, that they are therefore more expressive languages. It is their means that attract our attention, for we are eager to learn to what extent and in what ways expressive language can be elaborated and codified.

\section{DESCRIPTIVE ADVERBS IN GBEYA}

All African languages south of the Sahara, including such languages as Hausa and Somali (genetically related to Semitic languages) but with the possible exception of the Bushman-Hottentot languages, have words that are very similar formally and semantically. The phenomenon, which I call IDEOPHONY, is more highly developed in some languages than in others, but it is widespread enough to be considered pan-African, a characteristic of Africa as a linguistic area. (It is, for example, well developed in 
Adamawa Fula, but appears to be rudimentary in Wolof. Both of these languages are West Atlantic in classification. For Bantu languages, see Samarin [1971a: 159-161, 133-135].) In this study examples will be drawn only from Gbaya (an Ubangian language or language group of NigerKordofanian stock, spoken in the Central African Empire, and Cameroon, and Zaïre). My field experience, however, is exclusively with the dialect called Gbeya, which is for convenience spelled Gbeya. (For works on Gbeya, see Samarin, references.)

The phenomenon of ideophony was identified in African languages almost a hundred years ago. The term itself is my generalization from C. M. Doke's coinage, IDEOPHONE (1935: 118): "A vivid representation of an idea in sound. A word, often onomatopoeic, which describes a predicate, qualificative or adverb in respect to manner, colour, sound, smell, action, state or intensity." I would define IDEOPHONY as the foregrounding of phonological elements in word (or lexeme) composition in both spontaneous creations and fully institutionalized lexicon, usually associated with semantic categories of an attributive nature, commonly affective, and sometimes also in true onomatopoeia. Examples of ideophony in English are the following: Ugubugu (the name of a fictitious tribe created by an anthropologist on the spur of the moment), gooey goulash (a combination of conventional vocabulary by my wife to apologize for her supper); see also hully gully (a North American teen-age dance), flim flam, etc. (For a study of ideophones in English, see Thun [1963] and Samarin [1966b].)

Ideophony can manifest itself in any class of words if one takes it to be, as I do, a universal phenomenon. (For the universality of ideophone, see Samarin [1965] and Diffloth [1972], a case of convergence through independent work specializing in different language areas.) In some languages ideophony is found in some classes of words rather than others, and in some languages it occurs exclusively in one class or even subclass of words. Uniclass preference is the typical case of African languages. In Gbeya, ideophones constitute the subclass "descriptive adverbs" of the class "adverbs."1 In Zulu they make up a unique class.

The vocabulary of Gbeya looks as if it were assigned to two classes: one for expressive elements and another for the rest. This distinction parallels a formal-semantic one. Expressive words are primarily attributive in meaning ("slick," "instantaneous," "hot," "putrid," etc.). They are all members of the same word class by virtue of their syntactic behavior, that

1 There has been a fair amount of discussion about whether or not one could talk about African ideophones as a class of words and how they were to be identified. I seem to have been less explicit in print than I have been on other occasions. In any case, I would agree with Newman (1968) that it is better to avoid talking about ideophones generally as if they constituted a grammatical category. 
is, being adverbs instead of adjectives. ${ }^{2}$ And there is greater similarity within the class than with lexical elements in other classes. Thus, CV is a common shape of the verb; it is rare in ideophones. Verbs rarely have more than two syllables; ideophones commonly do. One can find close parallels between ideophonic and nonideophonic vocabulary (such as ding 'heavy' and dong 'back'; púm 'cleared' and pim 'tsetse fly'), ${ }^{3}$ but these are few indeed.

The phonological features that characterize the class consist of the following: nowhere else is voiced " $h$ " in contrast with the voiceless one; nowhere else are all words consistently high- or low-toned; nowhere else is reduplication used in the canonical form of the word (e.g. batata); nowhere else are certain compounding and echoic processes used (e.g. kalang kilong, gada guda, kirí wirí, zong dong); nowhere else does sound symbolism distinguish grades of differentiation (illustrated below).

It is the phonology of Gbeya ideophones, not their semantics, I must make clear, that is distinctive. In the first place, these words do have meanings that contribute to the total message of a sentence; they do not merely give color to the sentence. Notice the communicative importance of ideophones in the following contrastive sentences:

ã yóó gbákádá 'He stands fearless' (cf. å̉ yõngà tí-scráa gbákádá 'He gritted his teeth fearlessly' [iterally, 'he ate top of liver']). a yóó yézḱd dé 'He stands weak'.

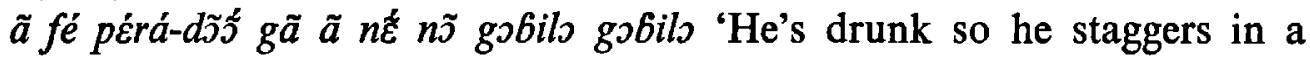
weaving manner'.

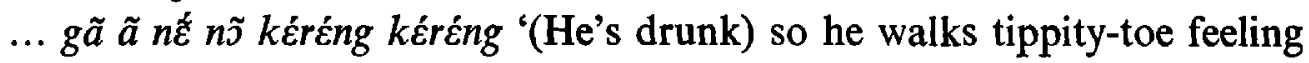
around before he puts his foot down'.

It is possible, therefore, to arrive at dictionary-type definitions for

2 There is in Gbeya virtually no crossing over from one class to another. Bantu languages have deverbative ideophones and de-ideophonic verbs, writers claiming to know what the direction of derivation is (Samarin 1971a). There are only occasional similarities: e.g. ndadak ndadak '(wood that) doesn't split well in chopping' (cf. ndadi 'to glue, adhere'), see Samarin (1966a: 89-90). Only a few nouns have ideophonic shape. However, ideophones behave as nouns with respect to tone when they function as preposed noun modifiers, e.g. gonggong'tuwa 'square house' (Samarin 1966a: 122). In insults this pattern is more common (Samarin 1969).

3 The orthography used here differs from my original one (Samarin 1966a) substantially and from subsequent ones superficially. Since my fieldwork in 1966 I have interpreted implosive stops and preglottalized nasals as conditioned variants, the latter occurring only in the environment of nasalized vowels and the stops elsewhere: e.g. [ $6 \mathrm{a}]$ and [?mã] written $6 a$ and $6 \tilde{a}$. Nasalization also conditions nasal continuants, which are now united with the prenasalized stops: [mba] and [mã] are interpreted as ma and $m \tilde{a}$. The sounds [n] and [ng] are represented as $n g$ whereas [nm] (coarticulated) and [nmgb] are represented as $n g m$. Voiced " $h$ " would be $h$. 
Gbeya ideophones. A tentative one for gadada will include the following kinds of information: descriptive of sticking or standing up or out (e.g. of ear, tail, or similar rigid appendage); occurs with verbs $y u$ 'flee', $n \tilde{\varepsilon}$ 'go',

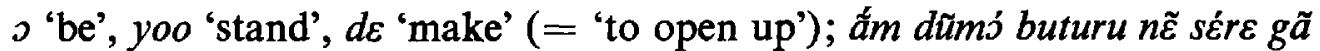
$\tilde{a} y \dot{u}$ 'I speared a Nile perch and it fled with the spear sticking out'. (A dictionary of Gbeya ideophones is in preparation, see Samarin 1971c.)

As for uniformity of meaning, I have already reported on the results of investigations and experiments I undertook among the Gbeya. For some words (like zólóló 'white') the meaning is as constant as it is for toró 'dog'. And if the meaning of other words, as illustrated below, varies somewhat, this is certainly a common phenomenon in language, especially of words with attributive or qualitative meanings (Samarin 1971b).

The Gbeya case may not be exactly what it is in other African languages, but neither can it be unique. I therefore suspect that statements made about some languages, especially those by people with a linguistically naive approach to the study of language, will have to be taken with a grain of salt. For example:

These words ... we may call Ideophones (notion-noises), since in very many we can feel that the sound immediately suggests the sense, and all leave us to relate the bare notion they convey to the necessary frame-work of actors, time and place. What is gained in vividness is lost in exactness of reference; but exactness is not always possible in creating or retailing a vivid impression, and ideophones are an excellent device for conveying essentials but leaving detail vague. They flash a series of pictures or sounds at us, to illustrate a situation already explained or actually present about us (T. Price 1958: 240).

Also: "The meanings are often indescribable" (E. Price 1947: 53); "The use of ideophones is similar to that of symbols in that it is not always easy to know exactly what is meant" (Krige 1968: 188).

Emphasis is being placed here explicitly on the fixed, that is, socialized, forms of these words. The intent is to underline the fact that features which, in other languages, are scattered about - a little here, a little there - in Gbeya appear to be collected in one place and exploited to their full advantage. (And we shall presently see that ideophones are also rendered, or "interpreted," in characteristic ways. Their occurrence in the stream of speech elicits a characteristic behavior in parole.)

The socialization and systematization of ideophones must be asserted without ambiguity. We are not confronted with words whose form or meaning depend on personal whim or unconscious factors. But this is what others, with perhaps less experience, have suggested. It has been said, for example, that speakers coin their own ideophones (Ziervogel 1952: 
160) and that the meanings of ideophones change drastically from one area to another (Doke 1954: 86). No support is given for these assertions about creating new ideophones, although experiments would not be difficult to devise. One or two casual remarks by native speakers (perhaps only a "I never heard the word before" to put off the inquirer) do not constitute proof. In all my experience I have found no evidence for wholesale coining, even though my opinions about the expressive function of ideophones would lead me to expect it. Informants may have disagreed with the phonetic form (e.g., ngbang instead of mbang) of a word or its meaning ("short" of a tree stump, not of a person), but they never said of a new word I had collected that it was unknown to them. This personal report, based on random incidents, is confirmed by work that one of my assistants did on my collection of (at that time) over 4,000 different words. I even collected ideophones from a group of children about six or seven years old and checked them with a group of adult males. Not a single one was deviant in any way.

Only once was I witness to what I thought was a word-creating event. I was seated with a family that was dividing up a pumpkin that had just been cooked for an afternoon snack when a three-year-old child, not yet fluent in his parents' language, said pérém pếrém with the obvious meaning of "I want pumpkin." The adults laughed in amusement at the child's ignorance of the proper name for pumpkin, say. It turned out that the child already knew at least one ideophone, and he was not wrong at all in asking for some "yummy" to eat. The ideophone, with low tone, means tasty without being sweet (like something with just the right amount of salt or like squash) and refers also to tongue-licking motions. Far from being wrong or ignorant, this child revealed knowledge about the word's meaning, and displayed an inherent linguistic capacity to generalize this knowledge. As he becomes socialized, the child will learn that his society is inhospitable to the nominalization of ideophones; they are extremely rare in Gbeya.

The socialization of descriptive adverbs in Gbeya is particularly salient by virtue of their great number. The main entries in my collection now stand close to 5,000. Another 6,000 emerge from the "synonyms" and "antonyms" provided in writing by my semiliterate assistants, but these words will have to be checked for accuracy. By comparison, there are only about 400 verbs in my collection of about 11,000 sentences illustrating the main entries. About 2,500 descriptive adverbs in my collection were originally compiled over a period of four years without any special effort being made, that is, while simply learning and speaking Gbeya daily. 


\section{GBEYA AND ENGLISH COMPARED}

Some of these observations are illustrated by comparing Gbeya and English vocabularies with respect to the concept "hot" (of temperature). The only nonideophonic means for making reference to this state in Gbeya is to use the locution ba wey 'take fire' (as in wesé aá sẽné gó baá wey 'The sun shone [i.e. poured] there so it has become hot'). One can also say of something: $\delta$ wey '[it] is hot'. Intensity ("very") can be expressed in both cases with a closing $n \tilde{\varepsilon}$ saa nấ, literally 'is fun no'. Beyond this, both for referential and expressive purposes, one must use ideophones. A sample of English and Gbeya words for hotness are compared:

\begin{tabular}{lll} 
& & "cool" \\
\hline English & Gbeya & Gbeya \\
burning & bắng & dống dống \\
searing & béng & dósósó \\
scorching & déréré & ớsósó \\
red-hot & héréré & ग̃soso \\
fiery & gbilling & tsisí \\
warm & kpókpókpó & ónónó \\
tepid & kpóyóng & ỹ̃koko \\
hot as hell & séséng & yíkiki \\
damn hot & sésésé & zokolom \\
nice and hot & ngévéng & \\
too hot to touch & ngbéng kéténg &
\end{tabular}

The salient features of the Gbeya words are: the preferred vowels are repeated in polysyllabic words; vowels are $e$ and $o$ (in Gbeya belonging to a harmonic set); there is a tendency toward repeated syllables; and high tone is preferred over low tone. When these words are compared with the words for "cool, cold," their saliency is brought into even sharper focus. Notice that with "cool," the vowels are $i$ and $\jmath$, vowel nasalization is prominent, tone is either high or low, and repetition is even more pronounced.

What is striking about this comparison is that English fails to exploit phonetic means to evoke the concept of hotness and to signal the semantic unity of the set. (If [hátata] or [háratatát] have ever been used by native speakers of English, the fact has probably gone unheralded.) But this is probably what is happening with the Gbeya sets for "hot" and "cool." Although it is referential meaning that brings these words together, it is 
clear that they are the product of some kind of process. English words are not reworked.

We do not intend to suggest that in other ways the sets of English and Gbeya terms are alike. The semantic differentiation of the members of the sets is certainly language-specific; the same is true for whatever subjective response is signaled in these words. In fact, at this stage of our analysis of Gbeya ideophones, we are not yet certain how these ideophones are related to each other. They come from different lists of synonyms for "(too) hot to touch." From personal experience I would say that most of them are very close if not identical in meaning. It should be noted, moreover, that all Gbeya ideophones are members of such formal-semantic sets. This is evident from the data, and I should expect it to be confirmed by experiment: given the syllable [ $f \hat{\varepsilon}$ ], fully socialized speakers of Gbeya would be expected to produce a constellation of ideophones with a core of soundmeaning similarity e.g. f́̂́b́ $b \dot{\varepsilon}$ 'narrow'.

It follows from what I have said that speakers of Gbeya would be able to detect (in a statistically significant way) words that were foreign to a set. Having examined my data for over a decade now, I feel sanguine about such a hypothesis being confirmed. In one list I prepared for "hot," for example, $\mathrm{I}$ found kpấyáng. This seemed wrong to me, unless it referred to hot oil. (I could not recall the word for "sizzling," but I thought its vowel was ã. Only later did I remember it: sãyaya.) It turns out that this word means 'clean as a well-swept yard'. There is also a word with low tone that imitates the sound of a bell. If the inclusion of kpấyáng was not an error, if one of my assistants did use it with the meaning "hot," then, for him, it constellated with words like sãyaya. There is evidence, in any case, that formal-semantic sets are not monolithic. They are not paradigmatic in any sense. Such structure would hardly be expected with words fulfilling an expressive function.

\section{SOUND SYMBOLISM}

Because the concept "hot" was chosen for convenience, being easy to gloss, it does not necessarily illustrate the full range of phonological processes that characterize the word class. In this paper, we will not, in fact, deal with them exhaustively. But, because sound symbolism has already been referred to as one of the manifestations of the expressive function, we should show how this appears in Gbeya. Here are several soundsymbolic lists. The verbs within parentheses illustrate the kind of verb with which the ideophones collocate. 
6it: (misi 'to flick, twitch') of the snapping up of the cord of a snare bet: $\quad(d \varepsilon$ 'to do, make') a quick, upward motion (like that of an animal's tail)

6et: $\quad$ of lifting a heavy object

bat: (mĩsi 'to flick, twitch', hũy 'to open') of sudden snapping up

6ut: ( $f \tilde{u}$ 'to explode, pop') sound of a joint (of bones) cracking or popping

6ot: (ỹ̃ng 'to eat, chew') sound of crunching something succulent

6ot: (dok 'to rub') sound of cracking or creaking

del: falling away

$d \varepsilon l$ : falling away

dul: (susi 'to swell, be swollen') of swelling, bulging (like a pocket)

dol: (suri 'to swell') of swelling (like lump on head)

dol ( $n \tilde{\varepsilon}$ 'to go, run') of up and down motion of an animal running

dal: $\quad(j$ 'to be') of being braced open (like the lid of a box), of bulging or being squat and large (like a covered typewriter)

Unexpected confirmation for this kind of socialized phonaesthetic ranking comes from a test for ideophone appropriateness (reported in Samarin 1971b). Gbeya subjects were asked to approve or disapprove of eighteen different words with the meaning "short, stocky, stubby, etc."

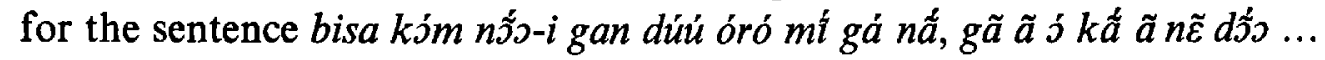
'This adolescent son of mine is not as tall as I am; he's short...' (literally, 'adolescent male of-me this-clitic negative is-tall like me like not and he is of him identifier short'). Of three words differing only in vowel quality, 95.6 percent agreed that ngbidi kiri was appropriate, 86.9 percent agreed that $n g b o d o$ koro was, and 71.7 percent agreed that ngbods kors was. Notice also that the meanings for these words are something like 'short and robust, solid (like a tree trunk)', 'short and heavy (like a log sawed off at both ends)', and 'short and flabby or obese (like a pregnant bitch), respectively.

Gbeya being a tone language, a pitch contrast is also used in ideophones to distinguish between small and large objects, high and low tones respectively. Thus, redeng is the common form with the meaning 'short', but if a Gbeya is asked if he can use rédźng, he might answer, for example, "Yes, that's for a child." This does not mean, however, that every occurrence of tone (or tone sequence) is automatically replaceable by the other, for tone is in some instances contrastive: e.g. lám lám 'quickly', lam lam 'distributed loosely, far apart'; ngbóng ngbóng 'far away', ngbong 'motionless'. It would appear that low-toned words can be said with high tones to mark "small," buthigh-toned words are not said with low tones to mark "big." 
In addition to this apparently regular marking of diminution by pitchraising, there may be others. Although the lexicon has not yet been analyzed with this problem in mind, the following kinds of contrasts appear: ri nź veyoo 'water is flowing out (before one's eyes)', ri nz̃à véyóó 'water has flowed out (as told to a second person)'; $e$ rat 'put something so that it sits snug and tight (as in the fork of a tree)', yoo rát 'stand (or be) strong, unflinching'; túrú kó mé $\mathfrak{j}$ wese wese 'your shirt is in rags', túrú kó $m \hat{\varepsilon} a \tilde{k} a ̀$ wés $\hat{\varepsilon}$ wésé 'your shirt has become (is) torn up'.

\section{IDEOPHONES IN EXPRESSIVE SPEECH}

Ideophones can occur in neutral or colorless speech, as in the sentence ãm zók ngmã te ñ̃ yóó mẽ peloo 'I see a tall tree standing there' (literally, 'I see tree stands there peloo'); when they do, there is nothing distinctive about the way they are delivered. (The long vowel oo in the example is part of the shape of the word; *pelo would be a nonce form.) But when speech is charged with emotion, ideophones are the focus of certain stylistic devices. Repetition is one of them. If the word already has a repeated syllable, it may be repeated at will. Thus, at the dramatic moment in a fable when Wan-to, the Spider, strikes the pots in which water has been hidden, the water bursts out and goes hadadadada pouring out. (The canonical form is hadada.) Complete words can also be repeated to indicate intensity, prolonged action, and other meanings. (It is possible also that repetition is sometimes just a way for providing oneself with vocal material for artistic manipulation.) Thus, in another story Wan-to trips

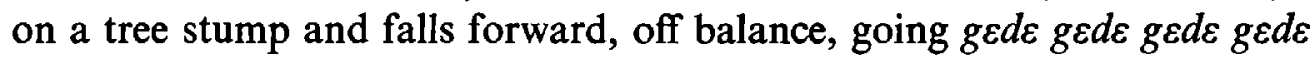

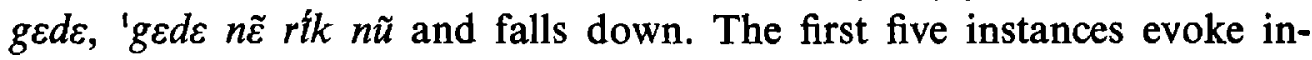
creasing speed as he hurtles forward. Suspense is broken by introducing the slight pause (,) and one more ged $\varepsilon$ with greater volume and intensity ('). Explicitness is fulfilled by $n \tilde{\varepsilon} r \hat{\imath} k n \tilde{u}$ 'and (he) falls ground', but this strikes me as an anticlimax.

A specifically ideophonic stylistic device is tone dropping on hightoned words. That is, all tones following the initial one are somewhat lower, but not as low as phonemically low tone, and level. This is true for both nonrepeated and repeated words, e.g. gbélḱk 'of being sound asleep', tólóló 'of being parched from thirst', mból mbjl 'of turning around slowly'.

The other phonological distortions to which ideophones are subjected do not differ in kind from those that characterize the stream of emotional speech (like increasing or decreasing volume, stressing the first syllable, lengthening vowels and consonants, raising or lowering level of pitch, 
modifying the vocal channel to produce sounds of anomalous quality, etc.), but it is possible that they differ in degree. I suspect that acoustic analysis will confirm my supposition.

It is not irrelevant that stylistic delivery of ideophones (or ideophonic stylistics) coincides with the characteristic syntax of ideophones. Final position in the sentence is their preferred location; only occasionally, and then only optionally, are they followed by some kind of complement (e.g.

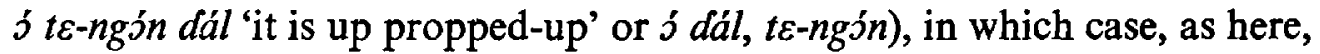
a pause is introduced.

It is not true that clauses with ideophones are simpler - having fewer syntactic elements or fewer words - than those without ideophones. Gbeya clauses are typically simple anyway. For example: ã sáá sék, sर́ $t \varepsilon$

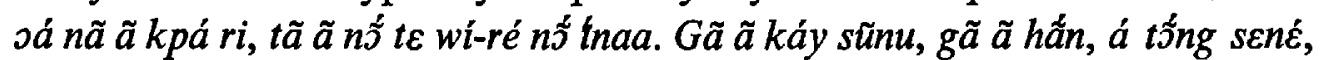
go rớk nế saa nắ, go ร̂́ rẽng rẽng 'He [the Spider] wondered how he and other people would find water to drink. So he took sesame, roasted it, added salt, making it very good and salty'. (Literally, 'he thinks, so that it would and he find water, and he drink then people drink with him. And he take sesame, then roast, put salt there, then it-be-good is fun no, then is yummywith-salt'.)

\section{IDEOPHONES IN LINGUISTICS}

The significance of ideophones for linguistics is that they reveal that language, as langue, can be adapted for expressive function to a greater degree than we had thought possible. They reveal that, although affect tends to be inimical to codification and socialization, it is not incompatible with them. There is a way for these two principal functions to coexist in linguistic structure. The trick is to utilize phonological processes that humans (for neurophysiological and psychological reasons not yet fully known to us) are inclined to adopt for mediating their subjective responses. The language may cheat just a bit, departing from the canons that govern all other lexemes. And whatever may be the origin of the wide selection of alternative elements for any concept, as above, with "hot," it contributes to a speaker's freedom in self-expression.

It is not necessary, of course, to try to account for the African specialization in an expressive lexicon. (Evidence suggests, however, that it can be traced to the ancestor of contemporary Niger-Congo languages.) Once the speakers got on to the trick and approved of its use, there was no particular reason - except for a sociopsychological one - why it should not go as far as it could. In Gbeya and related languages of the Ubangian 
group it has gone very far; in other languages, not anywhere near as far - or maybe a fully developed ideophony has virtually disappeared in them.

The present analysis would therefore appear to be a contribution to the fulfillment of Bühler's call for the comprehensive treatment of representation and expression: "La théorie du langage doit reconnaître et expliquer où et comment ce retour au sensible peut se faire que le langage lui-même soit détruit" (1969: 113). Onomatopoeia is a reversion, in his opinion, because language has evolved beyond the primitive needs and means of self-expression. The genius of language is its success at symbolic representation.

The present analysis also illustrates the adaptability of language for human needs: "The uses to which a tool is put, naturally react on the tool itself, especially in the case of a tool so sensitive and flexible as language" (Stern 1965: 23, cf. 184). Stern was talking explicitly about the influence of expression on language, but about its meaning, not its form (p. 173). In any case, for him, and others who have concerned themselves with semantic changes, words have individual histories (p. 42). If this is true of, for example, scrawl and scribble, I do not think that it is the whole truth for ideophones.

Whatever may be the truth about "individual histories" of words whose primary function is referential, it is wrong to think of ideophones as if they were individual organisms. Ngbéng kéténg '(too) hot to touch' may be formally different from - that is, not homophonous with - every other word in the constellation of words with this and similar (or contrastive) meanings, but it is surely not irrelevant that these words, like the words for "cool," have some "family" resemblance. It is semantics that brought these words together for our inspection. It was form that brought the following words together in a preliminary analysis of phonological form (here -ing, -eng, -ong). One can see, even from these very much abbreviated glosses, that we are confronted with a chain of related meanings:

$\begin{array}{ll}\text { kengeng kengeng } & \text { 'stiffly walking (wearing a bark clout)' } \\ \text { keng kedeng } & \text { 'stiff (shirt sleeves)' } \\ \text { teng teng } & \text { 'stiff (neck)' } \\ \text { tendeng } & \text { 'stiff (neck)' } \\ \text { zong dong } & \text { 'stiff (with cold)' } \\ \text { geng gereng } & \text { 'wide (elephant's ear)' } \\ \text { gong tong } & \text { 'wide (elephant's ass)' } \\ \text { gbong tong } & \text { 'wide (pant leg)' }\end{array}$




$\begin{array}{ll}\text { deng beteng } & \text { 'thick and heavy (elephant hide)' } \\ \text { ngbang ding } & \text { 'thick and heavy, covered with mud' } \\ \text { ding ding } & \text { 'thick and heavy (hoe blade)' } \\ \text { ndang ding } & \text { 'thick, fat' } \\ \text { mbong ding } & \text { 'dirty and wet [pejorative]' } \\ \text { ngbong dong } & \text { 'obese' }\end{array}$

Similarly, words for "rough to touch, scratchy" constellate with $k$ and the vowel $a$ : haka yaka 'of a pumpkin leaf, sandpaper, crocodile hide', saka yaka 'of dry sand', soko yoko 'of dry sand, food sauce that does not contain a mucilagenous vegetable (e.g. okra)', vakaka 'of upright sorghum stalks, scattered hairs on a pig's body', raka raka 'surface of a file or rasp, snake skin, turtle shell', sakada 'of calloused palm, log with bark; spiny'. These should be compared with words differing principally by the presence of nasalization, for example: vũngu yũngu 'of the surface of a certain caterpillar whose body is covered with hair', vãnga yãnga 'of the collection of twigs and leaves on the back of a certain insect, month-old growth of beard on a European's face', vẽngem vẽngem 'of itchy feeling after a certain pollen has fallen on one's body'. (The description of the relationship between, say, $[\breve{V k}]$ and [ $[\widetilde{V} \eta]$, in historical terms has not yet been made. There are Gbaya languages without nasalized vowels; see Samarin 1959.) The closest thing to this phenomenon in English is the existence of lists of words like cringe, crunch, craunch, squeak, screech, shriek, squawk, etc. But unlike Gbeya descriptive adverbs, these are for the most part onomatopoeic, and this is an important fact. Ideophones display the same kinds of processes even though they signal nonacoustic experience.

I suggest, therefore, a corollary of the axiom about word histories. Ideophones, as a class of words, have their own history. It is a fact that a word is a member of this class and that it has a certain kind of meaning and a specific syntactic behavior that makes the word what it is. Whatever its ultimate source might be (e.g. a verb, although this kind of derivation is not productive today in Gbeya, unlike most Bantu languages; or a borrowing from another language), it becomes naturalized in the associational environment of the others. ${ }^{4}$ Thus French zéro behaves just like an ideophone with the meaning 'a mile wide of the mark' (ấ rikó ã zero 'be struck [at] him missing him completely'), a meaning for which there are perfectly good Gbeya alternatives; yet zéro will, I suspect, lead to several others: * zeroro, *zere were. (The actual forms are wildly speculative.)

We should note, moreover, that, in being adapted to expressive function,

4 It should be noted that Gbeya has very little grammar at the level of the word, and word derivation by affixation and compounding is absent all together. 
African languages exploit certain phonological devices primarily with one class of words. Since language is by definition a system of arbitrary units, there is no reason why "spear" could not have been designated by gbang kalang, but it wasn't. SÉre is its name, and no other word approximates it. But gbang kalang 'wide' is related to others of its kind. This is not to say, of course, that gbang kalang is less arbitrary than sére with respect to its specific meaning. The point is that its form suggests its KIND of meaning. A comparable instance for nouns would be the word for butterfly: péré wéré.

If my attempt at accounting for ideophones falls short of the truth, this should not prevent us from trying again. The existence of such a large stock of words (in Gbeya certainly more than 5,000) similar to words in other languages that are few and sometimes anomalous should challenge us to provide an explanation. It is not an accident that Gbeya is rich in expressive adverbs; it could have managed somehow without them.

\section{IDEOPHONES FOR SOCIOLINGUISTICS}

If ideophones are significant for a more complete understanding of the nature of language, they are no less significant for an understanding of man's use of language. This division, in any case, is only a heuristic one. For some purposes it is useful to focus on one or the other aspect of language, but convenience is not license. Language requires us to look at it holistically. Expression is no less important than reference; it is just less disciplined. And we learn from African languages that this speech function is actualized adaptively in linguistic structure. What is the significance, then, of ideophones for the behavior of Africans whose languages abound in them? Is the quality of their psychic and social existence different from that of other people?

Sapir at one time in his career thought that word classes might have some such significance:

No language fails wholly to distinguish at least between noun and verb, although in some cases the distinction is an illusive one. It is, however, different with the other parts of speech. No one of them may be said to be imperatively required for the life of language, although they may greatly increase the fluidity and significance of that life.

Later, he chose to be more cautious and deleted the last clause in other editions of his work $(1921: 126) .{ }^{5}$ This was not because he felt less strongly

5 The quotation cited here, taken from Sapir's Language (p. 125), according to Urban (1939: 87), is not found in any edition I have consulted. In the original 1921 edition and 
about the consequences of language for man; rather, one would suppose, it was because this was not the best way of expressing it.

But one does not need to get embroiled in the controversy over linguistic determinism in addressing oneself to the question of linguistic relativity. Languages are different. The features that make them different - at whatever level of grammatical structure - demand, at the very least, identification and classification. But with relativity we imply that typology has a differential effect.

Linguistic resources lead to different patterns of speaking. In Gbeya one would not talk about Hawaii in the same way as the travel brochure quoted below:

[The lassitude] may come when [the visitor] sweeps back the curtain in his airconditioned hotel room to survey a velvety emerald view of rice fields, crew-cut golfing greens, jagged peaks with their heads in the clouds, or azure ocean.

Nor would a rock music concert be described as in the following newspaper article:

[Twenty], even ten rows back, the words can scarcely be heard. They exist not as nouns and verbs, but as a physical mass, a hot, indistinct slur like sausage meat: ground out of the famous lips, eaten by the mike, driven into banks of amplifiers and rammed out through two immense blocks of speakers high on either side of the stage. The vowels mix stickily with the air of the auditorium, already saturated by the fume of tens of thousands of packed bodies, the smoke of 50,000 cigarettes and a few pounds of weed, forming an acrid blue vault overhead.

In Gbeya one can talk about "velvety," "crew-cut," "slurred," "stickily," "packed," and so on, but doing this requires a differently structured text. And it is possible that talking this way would be possible in only certain contexts.

Differences in idiom, of course, need no demonstration. It is their nature and their consequence that require analysis. We are primarily concerned with consequences for the speech community itself, but linguistic relativity is also revealed in the history of language contact. The idiosyncracies of African languages, for example, have all been accepted by Europeans with practical or scientific concerns - even their use of tone.

the 1949 reprinting, this statement ends Chapter 5 on page 126 , not 125 . There are also significant textual changes: "No language wholly fails to distinguish noun and verb, though in particular cases the nature of the distinction may be an elusive one. It is different with the other parts of speech. Not one of them is imperatively required for the life of language." 
Only ideophones confronted the greatest resistance. Europeans either ignored them or assigned them, as we saw above, to marginal status as "vocal gestures," interjections, and the like. This was bias, of course, but not entirely naive. Europeans equated ideophones with their own ludic vocalizations; recognizing similarity in form, they assumed similarity of function. African languages, as a consequence, have been grossly misunderstood and underanalyzed.

If Europeans have been in contact with African speech, Africans have been in contact with European speech. This has already had consequences for African languages, and I suspect that ideophones are not invulnerable to change. But it is social change much more clearly than language contact that seems to have already affected the use of ideophones in Africa. I found during intensive research in Bangui, the capital of the Central African Empire, that the Gbeya who had spent most of their lives as city dwellers had a more imperfect knowledge of ideophones than their country cousins. By this standard, then, they demonstrate less competence. By the canons of contemporary linguistics, however, they are fully competent: they can still produce grammatical sentences and nativelike discourse. Yet the quality of their Gbeya must be judged to be different. These observations are supplemented by observations made in studying ideophones with a university-trained native speaker of Yoruba who had an excellent primary and secondary education in his native language. His knowledge of Yoruba ideophones was only vestigial; he also attributed their use to the smart-aleck, "half-educated" young people of his country. It is possible, therefore, that an aspect of the evolution being experienced by African languages is the emergence of rural and urban styles of speaking, one of whose differences is the use and nonuse of ideophones (to put it crudely). Perhaps the sophisticated speaker of Gbeya will some day say that his rural relative speaks in a colorful way.

The development of literacy is an aspect of Africa's culture change, and it has linguistic as well as social consequences. Not having investigated this matter, I am unable to report on what these consequences may be with respect to ideophones. In Nguni contemporary literature, according to the late A. C. Jordan, there is no dearth of them. But I would imagine that they are infrequent in vernacular newspapers. (By all reports they are virtually nonexistent in Bible translations and other religious publications, but until very recently these have been the work of missionaries.) In any case, we are not interested merely in the type or token frequency of ideophones in published literature but also in the way in which they are used. Moreover, we should expect writing to affect spoken language as we have found urban life doing so. There is evidence that similar words were much 
more common - indeed, fashionable - in sixteenth- and seventeenthcentury English than they are today (Thun 1963: 29).

Literacy returns us to the topic of relativity, because literacy represents a new stage in the sociolinguistic evolution of a language. One can claim, in fact, that languages that have gone through this experience are also linguistically different. Thus Paul Kay (1971) has revived a hypothesis mentioned by other authors but never fully exploited, that autonomous speech - that which is precise and logically explicit - is characteristic of communities speaking "advanced languages" (exemplified by world languages). What makes this autonomy possible, among other things, is the fact that the lexicons of these languages have evolved towards having more abstract AND more concrete words than local languages. It is tempting indeed to find in the African's predilection for ideophonic speech evidence for nonautonomous language-speech that is dependent on context for disambiguation.

One can find occasional parallels for this kind of dependence in our own highly explicit languages. I witnessed the following. In the subway a seated woman gestured to her standing friend, offering to take the package she was holding. The latter handed this to her, saying, "Yes, it's shugly ... (with erratic waving of one free hand). You know what I mean? ... Spineless!" Although I consider this neologism an instance of ideophony, I am not ready yet to turn over Gbeya adverbs to the support of the autonomy hypothesis. I may yet do so, but with several stipulations. For example, we must make a distinction between autonomous speech and autonomous lexicon. It is possible that in Gbeya there are both autonomous and nonautonomous uses of ideophones. It is also possible that some of these words have evolved toward greater autonomy than other words. And because this is a possibility, then African languages can differ with respect to the autonomy of their ideophones. Very much more work will have to be done on individual languages and then in comparing them before we can speak with certainty about these matters.

Kay rightly takes me to task for not attempting to account for the association of "backwoodsiness" with the use of ideophones on the part of city dwellers. His own suggestion, which I am happy to consider, is that urbanization is associated with language standardization where different varieties of the same language or different languages are in "conflict." This, of course, is consistent with my saying that urbanized Gbeya, for example, is pidginized. 


\section{REFERENCES}

BALLY, CHARLES

1926 Le langage et la vie. Paris: Payot.

BÜHLER, KARL

1969 "L'onomatopée et la fonction représentative du langage," in Essais sur le langage. Edited by J.-P. Pariente, 111-132. Paris: Les Editions de Minuit. (Partial translation of work originally published 1933 as Sprachetheorie. Jena: Fischer.)

DIFFLOTH, GÉRARD

1972 "Notes on expressive meaning," in Papers from the Eighth Regional Meeting of the Chicago Linguistic Society. Edited by Paul Perateau, Judith Levi, and Gloria Phares, 440-447. Chicago: Chicago Linguistic Society.

DOKE, C. $M$.

1935 Bantu linguistic terminology. London: Longmans, Green.

1954 The southern Bantu languages. London: Oxford University Press.

KAY, PAUL

1971 "Language evolution and speech style." Paper presented at the session on "The Relation of Anthropology and Linguistics in Honor of C. F. Voegelin," Annual Meeting of the American Anthropological Association, November 1971, New York City.

KRIGE, EILEEN JENSEN

1968 Girls' puberty songs and their relation to fertility, health, and morality among the Zulu. Africa 38: 173-198.

NEWMAN, PAUL

1968 Ideophones from a syntactic point of view. Journal of West African Languages 2: 107-117.

PRICE, E.

1947 "Ngombe grammar." Mimeographed. London.

PRICE, THOMAS

1958 The elements of Nyanja for English-speaking students. Blantyre: Church of Scotland Mission.

SAMARIN, W. J.

1959 Prospecting Gbaya dialects. African Studies 18: 68-73.

1965 Perspective on African ideophones. African Studies 24: 117-121.

1966a The Gbeya language. Berkeley and Los Angeles: University of California Press.

1966b Review of Reduplicative words in English by Nils Thun. Journal of African Languages 5: 161-163.

1967 Determining the meanings of ideophones. Journal of West African Languages 4 : $35-41$.

1969 The art of Gbeya insults. International Journal of American Linguistics $35: 323-329$.

1970a Field procedures in ideophone research. Journal of African Languages 9: 27-30.

1970b Inventory and choice in expressive language. Word 26: 153-169.

1971a Survey of Bantu ideophones. African Language Studies 12: 130-168. 
1971b "Measuring variation in the use of Gbeya ideophones," in Actes du huitième congrès de la Société Linguistique de l'Afrique Occidentale, volume two, 483-488. Annales de l'Université d'Abidjan, Série H, Fascicule hors série. Abidjan.

1971c "Semantics without native intuition." Paper presented at the Colloque International sur les Méthodes d'Enquête et de Description des Langues sans tradition écrite (Centre National de la Recherche Scientifique), June 1971, Nice.

1971d "Theory of order with disorderly data." Paper presented at the Annual Meeting of the American Anthropological Association, November 1971, New York City.

1972 Appropriateness and metaphor in the use of ideophones. Orbis 20: 356-369.

SAPIR, EDWARD

1921 Language. New York: Harcourt, Brace.

SLAMA-CAZACU, TATIANA

1961 Langage et contexte. Janua Linguarum, Series major 6. The Hague: Mouton.

STERN, GUSTAF

1965 Meaning and change of meaning. Bloomington: Indiana University Press. (Originally published 1931.)

THUN, NILS

1963 Reduplicative words in English. Lund: Carl Bloms Boktryckeri. URBAN, WILBUR M.

1939 Language and reality. London: George Allen and Unwin; New York: Macmillan.

ZIERVOGEL, $\mathrm{D}$.

1952 A grammar of Swazi. Johannesburg: Witwatersrand University Press. 